Personalidade Acadêmica Homenageada:

Florisbal de Souza Del'Olmo (Professor Convidado - UNICURITIBA)

\title{
DESAFIOS NA APLICAÇÃO DO NEOCONSTITUCIONALISMO AOS POVOS INDÍGENAS BRASILEIROS
}

\section{CHALLENGES IN THE APPLICATION OF NEOCONSTITUTIONALISM TO THE BRAZILIAN INDIGENOUS PEOPLES}

THAYSE EDITH COIMBRA SAMPAIO

Doutoranda em Direito pela Universidade de Brasília - UnB, linha de pesquisa "Constituição e Democracia", ingresso em 2019. Mestra em Direito pela Universidade Federal de Sergipe - UFS (2019). Advogada Inscrita № 15278 OAB-AL. Foi bolsista CAPES durante o mestrado. Graduação em Direito pela Universidade Estadual de Alagoas - UNEAL (2017). Foi participante do Núcleo de Pesquisa, Extensão e Assessoria Jurídica Popular (NEAJUP) da Universidade Estadual de Alagoas. Também participou do NEASR - Núcleo de Estudos Agrários e Movimento Sindical Rural em Alagoas. Foi bolsista PIBIC- FAPEAL. Possui experiência em pesquisa na área de Direito, em especial nos temas: Direito Indígena, Filosofia Contemporânea, Biopolítica, Constitucionalismo Latino Americano, Estudos subalternos e Direito Internacional Público. Aceita na Escola Internacional de Verão do projeto ALICE do professor Boaventura de Souza Santos. Atuou de forma voluntária, como Conciliadora da 8ª Vara Federal, localizada em Arapiraca -AL.

\section{RESUMO}

O presente artigo propõe debater o novo estágio do direito constitucional no Brasil e na Europa, denominado "neoconstitucionalismo". Na sequência, examina seus marcos: históricos -pós-guerra na Europa continental e a redemocratização no Brasil; filosóficos - o pós-positivismo, que está na confluência entre o jusnaturalismo e o positivismo, e teóricos- a força normativa da Constituição, expansão da 


\section{Personalidade Acadêmica Homenageada:}

\section{Florisbal de Souza Del'Olmo (Professor Convidado - UNICURITIBA)}

jurisdição constitucional, a irradiação sobre as normas inferiores e o desenvolvimento de uma nova dogmática interpretativa. Sempre atento as especificidades do constitucionalismo na América Latina. Finaliza problematizando, quais são os seus desafios para os povos indígenas brasileiros, a partir do julgamento do Caso Raposa Serra do Sol e do Estatuto do índio. Utiliza como referência básica o pensamento de Barroso e emprega uma pesquisa descritiva com análise de conteúdos. Visto que a intenção é revelar as ambiguidades do neoconstitucionalismo, quando o assunto é "povos indígenas".

PALAVRAS-CHAVES: Neoconstitucionalismo; Desafios; Povos Indígenas brasileiros.

\section{ABSTRACT}

This article proposes to discuss the new stage of constitutional law in Brazil and in Europe, called "neoconstitutionalism". In the sequence, it examines its milestones: history-post-war in continental Europe and redemocratization in Brazil; philosophical post-positivism, which is at the confluence between natural and positivism, and theoretical - the normative force of the Constitution, expansion of constitutional jurisdiction, the irradiation on the lower norms and the development of a new interpretative dogmatics. Always aware of the specificities of constitutionalism in Latin America. He ends by discussing, what are his challenges for the Brazilian indigenous peoples, based on the Raposa Serra do Sol Case and the Indian Statute judgment. It uses as a basic reference Barroso's thinking and employs a descriptive research with content analysis. Since the intention is to reveal the ambiguities of neoconstitutionalism, when the subject is "indigenous peoples".

KEYWORDS: Neo-constitutionalism; Challenges; Brazilian Indigenous Peoples. 
Personalidade Acadêmica Homenageada:

Florisbal de Souza Del'Olmo (Professor Convidado - UNICURITIBA)

\section{INTRODUÇÃO}

O direito constitucional percorreu, na Europa e no Brasil, uma longa trajetória que culminou no estágio hodierno, o neoconstitucionalismo. Esse triunfo ocorre tardiamente no país, quando comparado com a Europa, ${ }^{1}$ e enfrenta o desafio de se consolidar em um Estado que não atravessou satisfatoriamente algumas fases do desenvolvimento estatal. Nesse sentido, Barroso (2003, p.306) afirma que o "Brasil chega à Pós-modernidade sem ter conseguido ser liberal nem moderno."

A nova etapa constitucional se caracteriza pela aproximação entre o Direito e governos democráticos, e está preocupada com a realização da justiça. Pois, após graves fenômenos históricos, especialmente os autoritários, a dogmática jurídica vem enfrentando uma intensa crise existencial, que compromete a sua boa reputação.

O papel do intérprete/aplicador da norma é redefinido, não se encerrando em um distanciamento frio da realidade social, nos casos que the cabe analisar. Logo, o Poder Judiciário recebe uma nova atribuição, definida pelo constituinte originário, a proteção dos direitos fundamentais consignados na Carta Magna (BARROSO, 2003).

A progressividade do constitucionalismo está alinhada ao desenvolvimento do Estado, e registra, mais recentemente, o formato plurinacional, especialmente na América Latina. Essa designação representa, para a sociedade brasileira, a consagração e respeito às diversidades étnicas. Visto que, por seu intermédio todas as pluralidades, que são responsáveis pela formação nacional, passam a ser reconhecidas como sujeitos aptos à exigência de direitos.

Desse modo, a Constituição deixa de ser apenas um conjunto de métodos e procedimentos que limitam o poder. Torna-se capaz de mobilizar o imaginário das pessoas, em função do conjunto de garantias que estão positivadas no seu corpo, despertando um sentimento constitucional, também chamado de cultura constitucional (SILVA NETO, 2016). Entretanto, há aqueles, que apontam uma

\footnotetext{
${ }^{1}$ A exposição dos motivos estará presente no tópico que aponta os marcos históricos.
} 
Personalidade Acadêmica Homenageada:

Florisbal de Souza Del'Olmo (Professor Convidado - UNICURITIBA)

baixa incipiência do mesmo em terras tupiniquins, elencando entre os fatores que comprometem sua solidificação: os históricos, jurídicos e políticos.

No Brasil uma série de situações desmobilizam os indivíduos, podendo ser elencados: as marcas deixadas pelo processo colonizatório; a confusão do patrimônio público com o privado; o voto de cabresto; os altos custos para a participação na vida política do país; o individualismo; etc. (SILVA NETO, 2016).

A baixa adesão da sociedade brasileira ao sentimento constitucional compromete a força normativa-jurídica da CRFB/88. A centralidade do seu texto no ordenamento jurídico, disciplinando os limites dos poderes políticos, irradiando efeitos nas normas infraconstitucionais e marcando o início de uma nova dogmática interpretativa, são afetados pelo nível cultural do direito constitucional no país.

Essas teorias permitem realizar uma leitura elucidativa acerca dos desafios na concretização dos direitos fundamentais dos povos indígenas brasileiros. A partir de 1988, algumas garantias aos aborígenes passam a ocupar um topoi investido de proteção contra as mudanças legislativas oportunistas, e com uma potência realizadora superior a experimentada por normas que Ihe precederam.

No entanto, o contexto de violência que circunda os povos originários não sinaliza uma situação de fortalecimento dos seus direitos, ao revés apresenta os desafios que acompanham o novo estágio constitucional. Este estudo emprega uma pesquisa descritiva com análise de conteúdos, pois a intenção é revelar as ambiguidades do neoconstitucionalismo, quando o assunto é "povos indígenas". Este trabalho não se propõe a questionar a teoria apresentada por Barroso (2007), mas apontar quais circunstâncias postergam a sedimentação dessa mais recente etapa do direito constitucional, por isso é utilizada a análise de conteúdo, como técnica de pesquisa.

Essa jornada tem como ponto de partida os marcos históricos, filosóficos e teóricos, que inauguram o neoconstitucionalismo no Brasil e na Europa, sempre destacando os elementos que são mais significativos para esta investigação científica, que elenca a explicação: do pós-guerra e da redemocratização; jusnaturalismo e positivismo; expansão da jurisdição constitucional e nova ciência interpretativa; etc. como seus objetivos específicos. 
Personalidade Acadêmica Homenageada:

Florisbal de Souza Del'Olmo (Professor Convidado - UNICURITIBA)

\section{MARCOS HISTÓRICOS}

Segundo Barroso (2007), na Europa, o marco histórico do novo estágio constitucional foram as constituições pós-guerra e o surgimento de cortes para a proteção das mesmas, com ênfase nas experiências da Alemanha, Itália, Portugal e Espanha, nesta ordem. No Brasil, a redemocratização, após o período ditatorial, e a constituição de 1988 foram os principais responsáveis.

No velho continente, as inovações no texto constitucional, logo após a segunda guerra mundial, redefiniram a importância dos seus dispositivos para o controle das instituições modernas, como também estabeleceram uma nova posição para a Constituição no interior de um ordenamento jurídico. A proximidade entre constitucionalismo e democracia resultou em uma nova organização política, que apresenta diversas denominações: Estado Democrático de Direito, Estado Constitucional de Direito, Estado Constitucional Democrático (BARROSO, 2007).

Nas lições de Barroso (2007), na Alemanha a principal menção a esse novo direito constitucional é a Lei Fundamental de Bonn (1949) e a criação do Tribunal Constitucional Federal (1951). Ambos tiveram um papel determinante na elaboração de teorias e jurisprudências, que elevaram a posição do constitucionalismo nos países de tradição Civil Law. Na Itália, merece destaque a Constituição (1947) e a Corte Constitucional (1956). Nos anos 70, as constituições portuguesa e espanhola somaram valor no debate sobre o neoconstitucionalismo.

No Brasil essa experiência ocorre tardiamente, apenas em 1988. A nova normativa, semelhante ao que ocorreu na Alemanha, indicava uma fase de transição, capaz de conduzir a passagem de um regime autoritário a um Estado Democrático. Barroso (2007) sustenta que ela tem sido responsável pelo maior período de estabilidade institucional experimentado pelo país.

A capacidade de amparar conquistas e influenciar lutas por novos avanços sociais, tornam a Constituição Cidadã não só um texto escrito, mas o reflexo de um 


\section{Personalidade Acadêmica Homenageada:}

\section{Florisbal de Souza Del'Olmo (Professor Convidado - UNICURITIBA)}

novo anseio, que merece ser comemorado. Especialmente, diante de tempos nebulosos como os que aparentam chegar.

O judiciário passa a ser o guardião da Lei Maior, legitimado a atuar contrariamente aos poderes eleitos pela vontade popular, uma espécie de um poder contra majoritário. Barroso (2016) argumenta no sentido oposto ao americano Mark Tushnet $^{2}$, que defende um constitucionalismo popular. Pois, na opinião deste último autor, os direitos fundamentais teriam uma proteção maior nos cidadãos, na política e no legislativo; pontuando a possibilidade de revisão e rejeição das decisões judiciárias pelos poderes elegíveis, como na Nova Zelândia e Canadá. Ainda na perspectiva desse estudioso, a importância da Constituição não reside na proteção de alguns direitos fundamentais, mas ao disciplinar o funcionamento da política, campo responsável pelas decisões que importam verdadeiramente ao destino nacional.

Barroso (2016, p. 524) alega que na maioria dos países é conferido as cortes constitucionais a tarefa de vigiar e evitar a tirania das maiorias, "a essa circunstância, que gera uma aparente incongruência no âmbito de um Estado democrático, a teoria constitucional deu o apelido de 'dificuldade contramajoritária'." Entretanto, enfatiza que o significado de democracia não se reduz ao governo das multidões, todavia ao de todos, aí incluídos os grupos minoritários.

Diante da crise, que o Brasil vive na representação política, o judiciário passou a ocupar uma posição de maior representatividade diante da coletividade. Assim, explica-se o protagonismo que tem alcançado nas últimas décadas, complementando as omissões deixadas pelo legislativo, assegurando o respeito aos direitos fundamentais e garantindo uma punição adequada a aqueles, que se desviam das suas funções institucionais ou as utiliza para obter vantagens ilegais (BARROSO, 2016).

Quanto as críticas pertinentes a composição dos quadros do judiciário, Barroso (2016) lembra que qualquer indivíduo pode se tornar um juiz, exigindo-se, apenas, formação superior em direito e aprovação em concurso público. Para o

\footnotetext{
${ }^{2}$ Expoente do constitucionalismo popular. Outros nomes para o mesmo fenômeno são: Kramer (2004) e Waldron.
} 
Personalidade Acadêmica Homenageada:

Florisbal de Souza Del'Olmo (Professor Convidado - UNICURITIBA)

escritor, é mais simples integrar o poder judiciário do que ser eleito a um cargo político, visto que a elegibilidade está atrelada a altos custos financeiros.

$\mathrm{Na}$ sequência será exposto e discutido um grande marco histórico do constitucionalismo na América Latina, o Estado plurinacional.

\subsection{ESTADO PLURINACIONAL}

O Brasil viveu uma longa experiência como colônia de Portugal, fato que the logrou heranças até os dias atuais. A independência em 1822 não significou um processo completo, pois até meados do texto constitucional anterior era possível identificar resquícios de um direito alienígena, que foi transplantado para terras nacionais sem uma devida tradução jurídica. Outro ponto característico do constitucionalismo precedente era a implacável busca pela uniformidade da sociedade brasileira, ignorando a existência de uma série de grupos sociais: índios, campesinos, quilombolas, etc.

A estrutura do Estado Plurinacional se opõe as concepções tradicionais de Estado, pois incrementa uma série de novos valores e elege a democracia, amplamente participativa, como ferramenta para construir uma nova identidade nacional. Novos sujeitos ganham densidade e espaço político.

Uma sequência de movimentos sociais sucede no continente latinoamericano, contagiando as instituições e os poderes estatais, facilitando as mudanças no campo jurídico. Por vezes, esse processo foi denominado de neoconstitucionalismo ou constitucionalismo emancipatório e são reconhecidos pela capacidade de rebeldia e inconformidade com os modelos antigos. Contudo, merece atenção e destaque a iniciativa de algumas teorias que se preocupam com a possibilidade de submeter os acontecimentos jurídicos regionais às teorizações gerais, baseadas em garantias abstratas e formais (PRONER, 2013).

Nas últimas décadas, as jovens constituições em países da América do Sul implementaram uma reconciliação com o passado por meio de determinadas rupturas, esse movimento é chamado de decolonialidade. A historicidade do constitucionalismo americano é apresentada por Gargarella (2010) através de três 


\section{Personalidade Acadêmica Homenageada:}

\section{Florisbal de Souza Del'Olmo (Professor Convidado - UNICURITIBA)}

propostas: conservadora (elitista e moralmente perfeccionista); liberal (impessoal, sistema de freios e contrapesos, etc.); radical (maior representatividade política).

Um exemplo do último modelo, é a Constituição da Bolívia que operou um rompimento com o colonialismo (WOLKMER, 2013). No seu conteúdo é possível identificar um reconhecimento expresso ao caráter plurinacional do Estado e a autonomia e autogoverno para povos, nações e departamentos, somada a criação de mecanismos que assegurem a participação desses setores no governo (descentralização). Outros dispositivos que merecem destaque são: a inscrição da identidade cultural junto a cidadania bolivariana nas cédulas de identidade (art.30); educação intercultural; exercício político e jurídico a partir das cosmovisões indígenas e a jurisdição indígena (art. 190 a 192) (SAMPAIO; ÁVILA, 2017).

Um ponto que merece destaque é a criação de um Tribunal Constitucional Plurinacional (arts.196 a 204) competente para dirimir o conflito de competência entre as jurisdições. Seus membros são eleitos mediante sufrágio universal e as decisões devem estar pautadas no respeito a vida, defesa e demais garantias positivadas na Constituição.

No Brasil, o ordenamento jurídico anterior a 1988, reproduzia uma espécie de colonialismo interno. A constituição em vigor estabelece um novel regime político baseado na interculturalidade e cria subjetividades coletivas. Esses elementos rompem com o monismo jurídico e as fontes da produção legal brasileira, agora, excedem o ente estatal, reconhecendo outros modelos de organização social contrahegemônicos, no âmbito do pluralismo jurídico. Concebido como novas maneiras de enunciar o direito e definir a autoridade competente para aplicá-lo.

Em resumo, há uma refundação do Estado, da identidade nacional e do espaço público. Substituindo os sujeitos individuais e abstratos por coletividades participantes de inúmeras instâncias (membros do executivo, legislativo e judiciário). A produção legal busca respeitar a diversidade e o reconhecimento das normas comunitárias, aquelas elaboradas pela sociedade através de códigos próprios de conduta social. Desse modo, fica demonstrado a aproximação entre Direito e Democracia. 
Personalidade Acadêmica Homenageada:

Florisbal de Souza Del'Olmo (Professor Convidado - UNICURITIBA)

Esse encontro desenvolve novas fórmulas para a solução de conflitos entre normas constitucionais, amplia o campo participativo, estreitando as distâncias entre a parte deliberativa e os destinatários das leis, reforça que não existe hierarquia entre normas-regras e normas-princípio, cede espaço para o desenvolvimento do pluralismo e contempla direitos à diversidade de componentes da sociedade brasileira.

\section{MARCOS FILOSÓFICOS}

De acordo com Barroso (2007), o marco filosófico do neoconstitucionalismo é o pós-positivismo, situado entre o jusnaturalismo e o positivismo, correntes antagônicas. O novo estágio constitucional preserva a ideia de normas escritas, mas não se encerra nelas, ao aceitar a reaproximação com a filosofia e a moral. Estar na confluência entre esses dois extremos assinala a independência "[...] dos modelos puros por um conjunto difuso e abrangente de ideias, agrupadas sob o rótulo genérico de pós-positivismo" (BARROSO, 2007, p. 5).

O termo jusnaturalismo está fundamentado no direito natural e se desenvolve no século XVI. O mesmo foi uma das principais correntes filosóficas que acompanharam o Direito e assegura um catálogo de garantias independente da norma escrita, que buscam validade no conjunto de valores e pretensões humanas.

Essa crença representa inúmeras fases históricas, com conteúdos variados, associados à antiguidade clássica. Uma das variantes, que mais merecem atenção, é aquela que preconiza a razão, portanto a lei é resultado da intervenção racional e independência da revelação divina ou mitológica. Essa concepção avança e alcança seu apogeu no século XVII.

A razão é o domínio da inteligência sobre instintos, interesses e paixões que segue princípios universais. Segundo Barroso (2003) a razão sofreu dois grandes abalos, causados por Marx e Freud, nessa ordem. O primeiro, declarou que as crenças históricas, sociais e políticas guardam conexão com a posição social do indivíduo nas relações de trabalho, definidas pelo materialismo histórico, ou seja, a 


\section{Personalidade Acadêmica Homenageada:}

\section{Florisbal de Souza Del'Olmo (Professor Convidado - UNICURITIBA)}

razão não é guardiã da liberdade, mas presa da ideologia. O segundo, revela que o homem não é senhor das suas faculdades, pois está em estrita dependência com um poder imperceptível, que controla a psique, o inconsciente.

Ambos os autores, operaram uma mudança radical na compreensão do mundo, sobretudo a partir do potencial de transformação. Ao menos dois elementos centrais da dogmática jurídica são discutidos, a neutralidade e a objetividade. Esta última, sinaliza a existência de princípios e regras universais, que independem do ponto de vista observado (BARROSO, 2003).

$\mathrm{Na}$ opinião de Barroso (2003), a neutralidade crava um abismo da questão analisada, supõe um aplicador da lei livre das influências externas e das complexidades pessoais. Tonando-se um sujeito sem memória, sem história e sem ambições. O autor afirma que é desejável e possível, criar um intérprete desperto de sua postura ideológica, vez que sua conduta não significará a manutenção irrefletida da hierarquia social, baseada em uma distribuição de poder e rendas desigual.

Esses debates abrigaram a teoria crítica do direito, conjunto de ideias que questionam as principais premissas do saber jurídico tradicional, entre elas: estatalidade, neutralidade, objetividade, cientificidade, etc. A perspectiva crítica revela o caráter ideológico do direito, comparando-o à política e admite a possibilidade de sua existência além dos limites estatais. Cresce em um ambiente de fecunda interdisciplinaridade (BARROSO, 2003).

No Brasil, a teoria crítica do direito obteve adeptos e partilhou das mesmas bases do movimento europeu. Ambos, "[...] tinham como ponto comum a denúncia do direito como instância de poder e instrumento de dominação de classe, enfatizando o papel da ideologia na ocultação e legitimação dessas relações." (BARROSO, 2003, p. 316). Essa atitude filosófica conviveu com uma espécie de legalidade paralela marcada pela violência institucional.

A modernidade, a reforma protestante e a formação dos Estados nacionais possibilitaram o surgimento de um ambiente liberto das dependências teológicas, ideal para a elevação da razão. Essa atmosfera foi o elemento incinerante para duas importantes revoluções liberais: a francesa e a independência dos Estados Unidos. 


\section{Personalidade Acadêmica Homenageada:}

\section{Florisbal de Souza Del'Olmo (Professor Convidado - UNICURITIBA)}

Desse modo, o jusnaturalismo esteve ao lado do iluminismo, entusiasmando a elaboração do Código Civil francês, esse foi o instante em que o direito natural sofreu com a domesticação, sendo gradativamente codificado em normas escritas. Portanto, esse contexto de intensa positivação representa a sua superação histórica (BARROSO, 2003).

Conforme Barroso (2003), no final do século XIX o direito natural é abandonado pela ascensão do positivismo jurídico e a ciência jurídica experimenta profundas mudanças: equiparação à lei e distanciamento da filosofia. Consoante o pensador citado, a queda do direito natural é atribuída ao fascismo na Itália e nazismo na Alemanha, já que graves atentados à humanidade ocorreram sob o viés da legalidade. Após episódios de conflitos mundiais, a ética e os valores retornam ao direito.

Havia uma romântica confiança sobre a atividade intelectual, e a ciência se desenvolveu bastante nesse período. O positivismo jurídico se apropriou das metodologias das ciências exatas e naturais, nesse sentido a atividade judicial realizava um juízo de fato e não um de valor. Portanto, é possível identificar algumas características essenciais: a) aproximação quase plena entre Direito e normas; b) a afirmação da estatalidade do Direito: a ordem jurídica é uma e emana do Estado; c) a completude do ordenamento jurídico, que contém conceitos e instrumentos suficientes e adequados para a solução de quaisquer casos; d) inexistência de lacunas no sistema legal; e) formalismo: a validade da norma decorre da obediência a procedimentos previamente estabelecidos (BARROSO, 2003, p. 223 - 324).

Em meados do século $X X$, a rígida segregação entre direito e filosofia não correspondia ao estágio civilizatório da humanidade. Os estudiosos jurídicos não estavam satisfeitos com um regresso puro ao jusnaturalismo, recheado de fundamentos vagos e subjetivados. Assim, surge o pós-positivismo, como resposta as seguintes inquietações: insatisfação com a estrita legalidade que autorizou atos totalitários e inconformismo com a abstração dos direitos naturais (BARROSO, 2003).

Nesse sentido, ocorre um estreitamento de relações entre Direito e ética, materializada por princípios que estão abrigados no texto constitucional. Houve a 


\section{Personalidade Acadêmica Homenageada:}

\section{Florisbal de Souza Del'Olmo (Professor Convidado - UNICURITIBA)}

incorporação de novos valores, mas muitos foram ressignificados, tais como: o da separação de poderes e o Estado Democrático de Direito (BARROSO, 2003).

Entretanto, a novidade não reside na incorporação de novos preceitos, a exemplo da dignidade da pessoa humana, pois princípios oriundos dos textos religiosos e/ou filosóficos, a bastante tempo influenciam o campo jurídico, mesmo que sutilmente. $\mathrm{O}$ que existe de singular nessa hodierna dogmática jurídica é o reconhecimento da normatividade a esses valores, que atuam integrando o ordenamento e servindo de instrutor ao intérprete (BARROSO, 2003).

O trajeto dos princípios até o status de norma, não foi simples, por vezes esteve associado a uma dimensão puramente axiológica. Modernamente, as normas constitucionais se submetem a duas classes: normas-regras e normas-principio. Não há hierarquia entre elas, em função do principio da unidade da Carta Magna. A Constituição é visualizada como um sistema aberto, no qual as regras "[...] são proposições aplicáveis sob a forma de tudo ou nada (all or nothing)" (BARROSO, 2003, p.328) e os princípios, são cargas valorativas que apontam a direção a ser seguida.

A colisão dos princípios não pode estar sujeita a técnica de resolução de conflitos, tudo ou nada, mas sim a uma dimensão de peso e/ou importância. Diante dos elementos do caso concreto, o aplicador da lei deve efetuar a ponderação, articulando os valores em choque e sacrificando ao mínimo os direitos fundamentais em oposição. Sua marca deve ser o princípio da razoabilidade (BARROSO, 2003).

$\mathrm{Na}$ visão de Barroso $(2003$,$) o pós-positivismo influenciou sobremaneira a$ hermenêutica constitucional empregue na modernidade, por consequência é criado um catálogo de princípios instrumentais ao lado dos materiais. Atualmente, o processo interpretativo é desempenhado não só por juristas, como também pela sociedade, aproximando-se dos postulados do constitucionalismo popular.

Em síntese, essa recente etapa constitucional representa a superação do legalismo, por meio do reconhecimento de valores produzidos pela comunidade. Essa carga axiológica ingressa na legislação vigente, mesmo que ausente de positivação. Sua marca é o pluralismo jurídico, o surgimento de princípios e o desenvolvimento de uma nova hermenêutica (BARROSO, 2003). 


\section{MARCOS TEÓRICOS}

Três transformações revolucionaram a aplicação do direito constitucional: a) o reconhecimento de força normativa à Carta Magna; b) a expansão da jurisdição constitucional; c) o desenvolvimento de uma nova dogmática interpretativa. A partir do século $X X$, a Constituição adquire posição de norma jurídica, subvertendo o modelo que vigorava na Europa. Anteriormente, seu conteúdo tinha valor político e simbolizava um chamado à atuação dos governos. Ao Poder Judiciário não cumpria nenhum protagonismo na concretização do corpo constitucional (BARROSO, 2007).

Essas mudanças interferem na forma como o ensino da Constituição é repassado aos discentes, pois, agora, o docente está obrigado a expor o caráter vinculante, o reconhecimento de sua força normativa e a obrigatoriedade das suas disposições. As normas constitucionais adquirem os mesmos atributos das demais normas jurídicas (BARROSO, 2007). Logo, a sua inobservância desencadeia uma série de mecanismos direcionados ao cumprimento forçado.

O debate acerca da força normativa da Carta Magna só chegou ao Brasil no final da década de 80 , com a Constituição Cidadã. A explicação se encontra nas patologias crônicas, que acompanharam a biografia brasileira e nas antigas constituições, "[...] repositórios de promessas vagas e de exortações ao legislador infraconstitucional, sem aplicabilidade direta e imediata". (BARROSO, 2007, p. 8).

Nas lições de Barroso (2007), outra mudança importante foi a expansão da jurisdição constitucional, visto que até 1945, prevalecia um padrão de hegemonia do Poder Legislativo, influenciado pela doutrina inglesa (soberania do parlamento) e francesa (lei expressa a vontade da coletividade). Com as Leis Maiores na Alemanha e Itália, um novo modelo passou a inspirar os Estados, o da soberania da Constituição. Os direitos fundamentais passaram a ficar imunizados das alterações do legislativo, devido a atuação do judiciário. 
Personalidade Acadêmica Homenageada:

Florisbal de Souza Del'Olmo (Professor Convidado - UNICURITIBA)

Destarte, surgiram inúmeras cortes constitucionais, inicialmente na Alemanha (1951) e Itália (1956). E posteriormente, irradiaram por todo o continente europeu, Barroso (2007, p. 8-9) leciona:

\begin{abstract}
A tendência prosseguiu com Chipre (1960) e Turquia (1961). No fluxo da democratização ocorrida na década de 70 , foram instituídos tribunais constitucionais na Grécia (1975), na Espanha (1978) e em Portugal (1982). $E$ também na Bélgica (1984). Nos últimos anos do século XX, foram criadas cortes constitucionais em países do leste europeu, como Polônia (1986), Hungria (1990), Rússia (1991), República Tcheca (1992), Romênia (1992), República Eslovaca (1992) e Eslovênia (1993). O mesmo se passou em países africanos, como Argélia (1989), África do Sul (1996) e Moçambique (2003). Atualmente na Europa, além do Reino Unido, somente a Holanda e Luxemburgo ainda mantêm o padrão de supremacia parlamentar, sem adoção de qualquer modalidade de judicial review.
\end{abstract}

Barroso (2007) afirma, que o controle de constitucionalidade no Brasil existe desde de 1891 e era chamado de ação genérica; comportava-se semelhante a atual ação direta. De acordo com o estudioso, a Constituição de 1988 possibilitou o fortalecimento do direito de propositura e modernos modelos de controle de constitucionalidade eclodiram, como: a ação declaratória de constitucionalidade e a arguição de descumprimento de preceito fundamental.

Em terras nacionais, o controle de constitucionalidade pode ser efetuado pelos juízes de primeiro grau (controle difuso) e pelo Supremo Tribunal Federal (controle concentrado) $^{3}$ (BARROSO, 2007). Esta corte constitucional examina esse comando: a) em ações de sua competência originária (art.102, I da CRFB/88), b) em vias de recurso extraordinário (art. 102, II, da CRFB/88) e c) nas ações diretas - a ação direta de inconstitucionalidade (art. 102, I, a), a ação declaratória de constitucionalidade (arts. 102, I, a, e 103, $\S 4^{\circ}$ ), a ação direta de inconstitucionalidade por omissão (art. 103, $\S 2^{\circ}$ ), a arguição de descumprimento de preceito fundamental (art. 102, $\S 1^{\circ}$ ) e a ação direta interventiva (art.36, III).

O reconhecimento de que as normas constitucionais são normas de natureza jurídica, e não apenas política, demanda o surgimento de uma nova

\footnotetext{
${ }^{3}$ Contrapondo-se ao constitucionalismo popular, que postula o povo como intérprete último do texto constitucional.
} 


\section{Personalidade Acadêmica Homenageada:}

\section{Florisbal de Souza Del'Olmo (Professor Convidado - UNICURITIBA)}

maneira de interpretar os textos legais, a constitucional. Ela amplia os elementos tradicionais da hermenêutica do direito (gramatical, histórico, teleológico e sistemático) (BARROSO, 2007). Demonstrando, que as técnicas de resolução de conflitos entre normas - hierárquico, temporal e especial, são insuficientes para o novel modelo de direito constitucional.

As especificidades do texto constitucional conduziram os teóricos e intérpretes a sistematizarem um conjunto especial de princípios aplicáveis ao novo estilo interpretativo. São eles: a) Supremacia da Constituição, b) presunção de constitucionalidade das normas e atos do poder público, c) interpretação conforme a constituição, d) unidade, e) razoabilidade e f) efetividade (BARROSO, 2007, p. 11).

Barroso (2007) pontua que a hermenêutica tradicional não deverá ser afastada por completo, pois é pelo seu emprego que a maioria dos conflitos normativos são solucionados. Entretanto, foi diagnosticada pelos teóricos do direito constitucional uma situação de ausência no âmbito desta técnica, dado que surgiram séries de problemas atrelados à vontade do constituinte originário materializada no texto constitucional. Desse modo, desencadearam conceitos e categorias reunidos sob os auspícios da denominação "nova interpretação constitucional". O seu desenvolvimento está pautado sobre duas premissas: o papel da norma e o papel do juiz (BARROSO, 2007, p. 8).

Concernente a primeira premissa, tem-se que a descrição da norma deve oferecer a solução para as problemáticas jurídicas e, pertinente a tarefa do juiz, cabe ao mesmo localizar, a norma que melhor se aplica para a resolução do conflito. Em outros termos, o intérprete desempenha apenas uma tarefa automatizada do saber, pois a resposta para as adversidades estará contida, no ordenamento jurídico (BARROSO, 2007).

$\mathrm{Na}$ esteira de Barroso (2007), após os avanços do direito constitucional ficou demonstrado, que a abstração da lei não comporta a solução para todas as espécies de conflitos, e que a tarefa do magistrado foi redefinida. O juiz participa da elaboração do Direito ao lado do legislador. Inúmeras categorias (clausulas gerais, ponderação e a argumentação) surgiram como produto das recentes transformações. 
Personalidade Acadêmica Homenageada:

Florisbal de Souza Del'Olmo (Professor Convidado - UNICURITIBA)

As cláusulas gerais ou conceitos jurídicos indeterminados são sentenças abertas, que indicam um caminho de significados a serem completados pelo juiz, a depender do caso concreto, portanto são termos de muita plasticidade. Locuções como: ordem pública, interesse social e boa-fé, carecem de sentido para que seus alcances sejam estabelecidos. Nesse sentido, transferem ao intérprete uma dose importante de discricionariedade (BARROSO, 2007).

A colisão de normas constitucionais demanda a aplicação da ponderação, pois todas são dotadas de imperatividade e não podem ser afastadas. Por meio deste procedimento, o julgador fará permissões bilaterais entre os interesses em contenda, procurando preservá-los. Optará pelo direito que oferecer a resposta mais adequada para a situação, ou seja, aquela capaz de manter a vontade do constituinte originário. Mas, há casos difíceis de obter uma solução, visto que comportam mais de uma resposta adequada, para resguardar a legitimidade e racionalidade, Barroso $(2007$, p. 15$)$ indica que o intérprete deverá, com relação a decisão que proferir:

(i) reconduzi-la sempre ao sistema jurídico, a uma norma constitucional ou legal que Ihe sirva de fundamento - a legitimidade de uma decisão judicial decorre de sua vinculação a uma deliberação majoritária, seja do constituinte ou do legislador; (ii) utilizar-se de um fundamento jurídico que possa ser generalizado aos casos equiparáveis, que tenha pretensão de universalidade: decisões judiciais não devem ser casuísticas; (iii) levar em conta as conseqüências práticas que sua decisão produzirá no mundo dos fatos.

Em resumo, o neoconstitucionalismo consiste em uma série de modificações no direito constitucional e na figura estatal. Barroso (2007, p.16) destacada como marco histórico dessas transformações, a formação do Estado Constitucional em meados do século XIX, como marco filosófico, o pós-positivismo, que reposiciona a Constituição no centro do ordenamento jurídico e a aproxima da ética e como marco teórico, a força normativa da Carta Magna, a expansão da jurisdição constitucional e o aparecimento de uma nova dogmática interpretativa. 
Personalidade Acadêmica Homenageada:

Florisbal de Souza Del'Olmo (Professor Convidado - UNICURITIBA)

\subsection{A IRRADIAÇÃO DAS NORMAS INFRACONSTITUCIONAIS E O ESTATUTO DO ÍNDIO}

Conforme destacado nas seções anteriores, um dos marcos teóricos do constitucionalismo emancipatório ou neoconstitucionalismo é o efeito irradiador das normas da Lei Maior, sobre todo o sistema jurídico. Esse impacto é conhecido como constitucionalização de direitos, contudo a terminologia também compreende um outro sentido, a positivação de dispositivos da legislação inferior na Carta Magna. Frise-se, que este último intento não é o objeto de discussão deste item.

Portanto, a análise aqui desenvolvida está atenta ao fenômeno, que estimula uma adaptação das leis infraconstitucionais à vontade do texto constitucional. A atividade interpretativa deve estar pautada nos valores presentes na Constituição.

Pertinente aos povos nativos do Brasil, existe uma legislação específica anterior ao nascimento da atual CRFB, a lei 6.001/1973 - Estatuto do índio. O ambiente em que essa norma foi elaborada não refletia os fatores históricos do novo constitucionalismo. Pois, enquanto este, assegura uma série de direitos a todos os povos originários (aculturados ou não), aquela, informa garantias jurídicas, apenas, aos que ainda não foram incorporados a unidade nacional. É por isso que classifica os indígenas em: isolados, em vias de integração e integrados.

Os direitos consagrados no conteúdo do Estatuto do índio, o acompanham até a completa incorporação à comunhão nacional (art. 4, III), ou seja, há um teor assimilacionista que contradiz a ideia de Estado Plurinacional. No território nacional vivem mais de 300 etnias de povos originários, alguns ainda em isolamento da sociedade nacional.

Cada grupo é culturalmente diverso, ainda que recebam a mesma alcunha, indígenas. São divindades, línguas, costumes, organizações sociais, hábitos e histórias distintas, que se aproximam pela diversidade, pela violência histórica que foram vítimas e pela resistência em manter o conhecimento tradicional.

Desse modo, percebe-se a incompatibilidade entre as intenções da legislação específica e os valores constitucionais. Forçar que centenas de povos 
Personalidade Acadêmica Homenageada:

Florisbal de Souza Del'Olmo (Professor Convidado - UNICURITIBA)

sejam uniformizados é contrário ao primado do Estado Plurinacional e Multiétnico, que representa um importante marco do neoconstitucionalismo na América Latina.

\subsection{A EXPANSÃO DA JURISDIÇÃO CONSTITUCIONAL, O DESENVOLVIMENTO DE UMA NOVA DOGMÁTICA DA INTERPRETAÇÃO CONSTITUCIONAL E O CASO RAPOSA SERRA DO SOL}

Sob os auspícios de proteção do texto constitucional, ocorre a expansão da jurisdição responsável pela sua preservação. No diálogo com o tema apresentado na introdução, os povos indígenas brasileiros, apresenta-se o julgamento do caso Raposa Serra do Sol pelo Supremo Tribunal Federal em 2013. No exemplo indicado, a corte foi instada a decidir acerca da regularidade da demarcação da terra indígena Raposa Serra do Sol, em Roraima; direito assegurado pela CRFB/88 no artigo 231 . Os ministros reconheceram a validade da portaria e do decreto presidencial que declaravam a ancestralidade do território, porém fixou alguns parâmetros para a compreensão do que vem a ser "terras tradicionalmente ocupadas por povos indígenas".

A tese do marco temporal submete o processo demarcatório à comprovação, de que as terras eram ocupadas pelos nativos na data da promulgação da Constituição Federal de 1988. Adicionalmente, a efetiva relação dos gentios com a localidade (marco da tradicionalidade da ocupação). Cria uma restrição ao direito constitucional do artigo $231 \mathrm{CRFB} / 88$, que não é identificada na leitura literal do dispositivo. Para tanto, não considera as determinantes que expulsaram esses povos de seus territórios. Conflitando com a jurisprudência do Sistema Interamericano de Direitos Humanos, que não define a ocupação por critérios de tempo, senão pela relação espiritual que os mesmos mantêm com a superfície que habitam. 
Personalidade Acadêmica Homenageada:

Florisbal de Souza Del'Olmo (Professor Convidado - UNICURITIBA)

A teoria do marco temporal não subjaz o sentimento de dignidade de muitas comunidades aborígenes. Condiciona o reconhecimento do direito à posse das terras que residem, desde tempos imemoriais, à limites temporais.

A cultura jurídica brasileira propaga práticas discursivas inexatas em face dos povos autóctones, pois as: a) garantias constitucionais (arts. 231 e 232 da CRFB/88) reconhecem aos nativos a organização social, cultura, tradições, posse das terras ancestrais, etc; b) a legislação específica (lei 6.001/1973); c) os tratados internacionais de direitos humanos, como a Convenção 169 da OIT (Decreto $5.051 / 2004)$ e outros, quando confrontados com a realidade, revelam uma força normativo-concretizadora ineficiente.

O resultado dessa decisão não expressa a essência do neoconstitucionalismo. É possível verificar a suposta tentativa do judiciário em proteger a Carta Magna por intermédio de um tribunal constitucional, ao incluir em sua pauta um julgamento importante. Entretanto, para a resolução do conflito em exame, a técnica interpretativa empregada não foi a mais adequada, porque resultou em quase nada ${ }^{4}$ aos aborígenes. O ideal seria uma ponderação entre os interesses em atrito, desde que observadas as consequências históricas dos episódios hostis às populações nativas do Brasil. Se a intenção desse novo estágio do direito constitucional é revelar a vontade do constituinte originário, por que emitir um entendimento (marco temporal e tradicional da posse) que restringe o direito à propriedade dos povos indígenas, previsto no artigo 231 da CRFB/88? Esse dispositivo é dotado de imperatividade, característica das normas constitucionais no paradigma pós-positivista?

\section{CONCLUSÃO}

\footnotetext{
${ }^{4}$ Em alusão a resolução de conflitos entre regras mediante o tudo ou nada.
} 
Personalidade Acadêmica Homenageada:

Florisbal de Souza Del'Olmo (Professor Convidado - UNICURITIBA)

1. Na opinião de Barroso (2007), o neoconstitucionalismo triunfou tardiamente em terras brasileiras, quando comparado com outros países da Europa Continental;

2. Segundo Barroso (2007) o novo direito constitucional enfrenta o desafio de se consolidar em um Estado que não atravessou satisfatoriamente algumas fases do desenvolvimento estatal;

3. A nova etapa constitucional se caracteriza pela aproximação entre o Direito e a Democracia;

4. O papel do intérprete da norma é atualizado, não se encerrando em um distanciamento frio da realidade social, e cabe ao Poder Judiciário a proteção dos direitos fundamentais consignados na Carta Magna;

5. Com isso, a Constituição deixa de ser apenas uma técnica e se torna capaz de mobilizar o imaginário das pessoas (sentimento/cultura constitucional) devido a série de direitos que estão positivados no seu interior;

6. No Brasil uma série de situações desmobilizam os indivíduos e como consequência, ocorre a baixa adesão da sociedade brasileira ao sentimento constitucional comprometendo a força normativa-jurídica da CRFB/88;

7. A centralidade no ordenamento jurídico, a irradiação de efeitos nas normas infraconstitucionais e o início de uma nova dogmática interpretativa, são afetados pelo nível cultural do direito constitucional no país e os povos indígenas espelham esse dado;

8. Esse estudo tem como ponto de partida os marcos, apontados por Barroso (2007), históricos, filosóficos e teóricos, que inauguram o neoconstitucionalismo no Brasil e na Europa;

9. Para Barroso (2007), as constituições pós-guerra e o surgimento de cortes para a proteção delas, com ênfase nas experiências da Alemanha, Itália, Portugal e Espanha, nesta ordem. E no Brasil, a redemocratização e a constituição de 1988, são definidos como os marcos históricos do novo constitucionalismo;

10. Barroso (2016) se opõe as teorizações de Mark Tushnet, argumenta que diante da crise representativa que o país vive, o poder judiciário passou a ocupar o papel de maior representatividade dos anseios da coletividade brasileira; 
Personalidade Acadêmica Homenageada:

Florisbal de Souza Del'Olmo (Professor Convidado - UNICURITIBA)

11. O neoconstitucionalismo tem uma marca distintiva no continente americano, o Estado Plurinacional;

12. A estrutura do Estado Plurinacional se opõe as concepções tradicionais de Estado, pois incrementa uma série de novos valores e elege a democracia amplamente participativa como ferramenta para construir uma nova identidade nacional;

13. De acordo com Barroso (2007), o marco filosófico do neoconstitucionalismo é o pós-positivismo, situado entre o jusnaturalismo e o positivismo, correntes de pensamento antagônicas;

14. A expressão "jusnaturalismo" está fundamentada no direito natural e se desenvolve no século XVI;

15. O direito natural sofreu uma profunda domesticação, ao inspirar a positivação de direitos, tornando-se o marco da sua decadência;

16. O positivismo jurídico desenvolveu uma romântica crença na cientificidade e importou a metodologia das ciências exatas;

17. Em Barroso (2007), o paradigma positivista apresenta as seguintes características: a) aproximação quase plena entre Direito e normas; b) a afirmação da estatalidade do Direito; c) a completude do ordenamento jurídico; d) inexistência de lacunas no sistema legal; e) formalismo;

18. Em meados do século XX, assinala Barroso (2007), a rígida segregação entre direito e filosofia não correspondia ao estágio civilizatório da humanidade. Logo, surge o Pós-positivismo, que reaproximou o direito da filosofia e resultou na incorporação de uma dimensão axiológica à CRFB/88;

19. Barroso (2007) postula, que três transformações revolucionaram a aplicação do direito constitucional e são reconhecidas como o seu marco teórico: a) o reconhecimento de força normativa à Carta Magna; b) a expansão da jurisdição constitucional; c) o desenvolvimento de uma nova dogmática interpretativa;

20. O debate acerca da força normativa da Carta Magna só chegou ao Brasil no final da década de 80, com a Constituição Cidadã. A explicação se encontra nas patologias crônicas, que acompanharam a biografia brasileira. Nesse 
Personalidade Acadêmica Homenageada:

Florisbal de Souza Del'Olmo (Professor Convidado - UNICURITIBA)

sentido, é preciso destacar, que a força normativa-concretizadora da CRFB/88 é seletiva, pois não alcança adequadamente os povos originários;

21. O reconhecimento de que as normas constitucionais são também normas jurídicas, demanda o surgimento de uma nova modalidade de interpretação, a constitucional. Esta, por sua vez, amplia os elementos tradicionais da hermenêutica do direito. Contudo, isto não parece crível, quando se trata das populações aborígenes;

22. A irradiação constitucional sobre as normas infraconstitucionais é conhecida como constitucionalização de direitos;

23. O Estatuto do índio não exemplifica esse fenômeno irradiador de efeitos, visto que não reflete os fatores históricos do novo constitucionalismo;

24. O julgamento do caso Raposa Serra do Sol pelo Supremo Tribunal Federal informa a expansão da jurisdição constitucional sobre a matéria indígena. Porém, a técnica interpretativa empregada não foi a mais adequada, porque resultou em quase nada aos nativos. O ideal seria uma ponderação entre os interesses em atrito, observadas as consequências históricas, que fizeram desses povos, vítimas;

25. O neoconstitucionalismo não autoriza o intérprete a limitar a intenção do constituinte originário, semelhante ao acontecido no caso examinado, através da formulação das teorias do marco temporal e da tradicionalidade.

\section{REFERÊNCIAS}

BARROSO, Luis Roberto. Interpretação e aplicação da Constituição. 5 ed. São Paulo: Saraiva, 2003.

. Neoconstitucionalismo e constitucionalização do direito (o triunfo tardio do direito constitucional no Brasil. In: SOUZA NETO, Claudio Pereira de; SARMENTO, Daniel. A Constitucionalização do Direito: Fundamentos Teóricos e aplicações específicas. Rio de Janeiro: Lumen Juris, 2007.

A razão sem voto: a função representativa e majoritária das cortes constitucionais. In: Revista de Estudos Institucionais, v. 2, n. 2, 2016. 
Personalidade Acadêmica Homenageada:

Florisbal de Souza Del'OImo (Professor Convidado - UNICURITIBA)

BRASIL. Constituição (1988). Constituição da República Federativa do Brasil. Brasília, DF: Senado, 1988.

Senado, 1973.

Estatuto do Índio. Lei № 6.001, de 19 de dezembro de 1973. DF:

Supremo Tribunal Federal. EMBARGOS DE DECLARAÇÃO. AÇÃO POPULAR. DEMARCAÇÃO DA TERRA INDÍGENA RAPOSA SERRA DO SOL № 3.388 - RO. Relator: Ministro Roberto Barroso. Brasília- DF, 23 de outubro de 2013. Lex: Jurisprudência do STF.

GARGARELLA, R. El nuevo constitucionalismo latinoareicano. Algunas reflexiones preliminares. Critica y Emancipación, Revista Latinoamericana de Ciencias Sociales, a. II, n. 3, 2010, p. 169- 188.

NEVES, Marcelo. A Constitucionalização Simbólica. São Paulo: Martins Fontes, 1994.

PRONER, Carol. O Estado Plurinacional e a Nova Constituição Boliviana: contribuições da experiência boliviana ao debate dos limites ao modelo democrático liberal. In: WOLKMER, A.C.; MELO, M.P. (Org.). Constitucionalismo LatinoAmericano: tendências contemporâneas. Curitiba: Juruá, 2013. p. 141 - 152.

SAMPAIO, Thayse Edith Coimbra; ÁVILA, Flávia. Tendências do Constitucionalismo Andino: contribuições do giro biocêntrico à dogmática jurídica tradicional. In: XVI Congresso Internacional FoMerco, Salvador, 2017. Anais eletrônicos. Disponível em:

http://www.congresso2017.fomerco.com.br/resources/anais/8/1504145909 ARQUIV O ArtigoFomercoSalvador2017FINALIZADO.pdf>.

SECRETARIA DOS DIREITOS HUMANOS DA PRESIDÊNCIA DA REPÚBLICA. Jurisprudência da Corte Interamericana de Direitos Humanos: Direitos dos povos indígenas. Disponível em:< http://www.sdh.gov.br/assuntos/atuacaointernacional/sentencas-da-corte-interamericana/pdf/direitos-dos-povos-indigenas $>$. Acesso em: 28 de novembro de 2017.

SILVA NETO, Manoel Jorge e. O Constitucionalismo Brasileiro Tardio. Brasília: ESMPU, 2016.

WOLKMER, Antonio Carlos. Pluralismo Crítico e Perspectivas para um novo Constitucionalismo na América Latina. In: WOLKMER, A.C.; MELO, M.P. (Org.). Constitucionalismo Latino-Americano: tendências contemporâneas. Curitiba: Juruá, 2013. p. 19-42. 